\title{
UPAYA PENINGKATAN AKTIVITAS SISWA KELAS VII PADA PEMBELAJARAN PKN DENGAN MENGGUNAKAN MODEL PEMBELAJARAN KOOPERATIF TIPE JIGSAW DI SMP NEGERI 5
}

\author{
Netti Simanungkalit \\ Surel: nettisimanungkalit07@gmail.com
}

\begin{abstract}
ABSTRAK
Penelitian ini bertujuan untuk meningkatkan aktivitas siswa pada mata pelajaran PKn melalui model pembelajaran kooperatif tipe Jigsaw. Penelitian ini adalah penelitian tindakan kelas (PTK). Penelitian tindakan kelas ini menggunakan model Kemmis $\mathrm{M}$ targart, dimana dalam setiap siklusnya terdiri dari kegiatan perencanaan, pelaksanaan, observasi dan refleksi. Penelitian ini dilaksanakan sebanyak 2 siklus. Yang menjadi subjek pada penelitian ini adalah siswa kelas VII SMP Negeri 5 kota Tebing Tinggi. Penelitian ini menggunakan teknik analisis dekriptif kualitatif, yaitu suatu metode penelitian yang bersifat menggambarkan kenyataan atau fakta sesuai dengan data yang diperoleh. Penerapan Pembelajaran dengan model Jigsaw materi kebebasan mengemukakan pendapat pada mata pelajaran PKN di kelas VII SMP Negeri 5 kota Tebing Tinggi memiliki dampak positif dalam meningkatkan aktivitas belajar siswa yang ditandai dengan peningkatan aktivitas dan motivasi siswa dalam setiap siklus, dan dinyatakan berhasil.
\end{abstract}

Kata Kunci : Aktivitas Belajar, Model Pembelajaran Kooperatif Tipe Jigsaw

\section{PENDAHULUAN}

Pendidikan Kewarganegaraan (PKn) diberikan sejak SD sampai SLTA. Dengan PKn seseorang akan memiliki kemampuan untuk mengenal dan memahami karakter dan budaya bangsa serta menjadikan warga negara yang siap bersaing di dunia internasional tanpa meninggalkan jati diri bangsa. Melalui PKn setiap warga negara dapat mawas diri dengan perkembangan teknologi informasi dan komunikasi dewasa ini yang memberi dampak positif dan negatif. PKn juga bermanfaat untuk membekali peserta didik agar memiliki kemampuan untuk mengelola dan memanfaatkan informasi untuk bertahan hidup pada keadaan yang selalu berubah, tidak pasti dan kompetitif. Pada kenyataannya, PKn dianggap ilmu yang sukar dan sulit dipahami. PKn adalah pelajaran formal yang berupa sejarah masa lampau, perkembangan sosial budaya, perkembangan teknologi, tata cara hidup bersosial, serta peraturan kenegaraan. Begitu luasnya materi PKn menyebabkab anak sulit untuk diajak berfikir kritis dan kreatif dalam menyikapi masalah yang berbeda. Sementara anak usia sekolah dasar tahap berfikir mereka masih belum formal, karena mereka baru berada pada tahap Operasi Onal Konkret (Peaget : 1987). Apa yang dianggap logis, jelas dan dapat dipelajari bagi orang dewasa, kadang - kadang merupakan hal yang tidak masuk akal dan membingungkan 
bagi siswa. Akibatnya banyak siswa yang tidak memahami konsep PKn. Pada SMP Negeri 5 kota Tebing Tinggi sejak peneliti mengajar, dalam pembelajaran $\mathrm{PKn}$ peneliti sering menggunakan model pembelajaran ceramah. Model pembelajaran ini tidak dapat membangkitkan aktivitas siswa dalam belajar. Hal ini tampak dari perilaku siswa yang cenderung hanya mendengar dan mencatat pelajaran yang diberikan guru. Siswa tidak mau bertanya apalagi mengemukakan pendapat tentang materi yang diberikan. Melihat kondisi ini, peneliti berusaha untuk mencarikan model pembelajaran lain yaitu model pembelajaran diskusi. Siswa dibagi atas beberapa kelompok yang beranggotakan 4-5 orang (melihat kondisi siswa di kelas). Dari diskusi yang telah dilaksanakan, ternyata siswa masih kurang mampu dalam mengemukakan pendapat, sebab kemampuan dasar siswa rendah. Dalam bekerja kelompok, hanya satu atau dua orang saja yang aktif, sedangkan yang lainnya membicarakan hal lain yang tidak berhubungan dengan tugas kelompok. Dalam melaksanakan diskusi kelompok, peneliti juga melihat di antara anggota kelompok ada yang suka mengganggu teman karena mereka beranggapan bahwa dalam belajar kelompok (diskusi) tidak perlu semuanya bekerja. Karena tidak semua anggota kelompok yang aktif, maka tanggung jawab dalam kelompok menjadi kurang, bahkan dalam kerja kelompok (diskusi), peneliti juga menemukan ada di antara anggota kelompok yang egois sehingga tidak mau menerima pendapat teman.

Melihat kenyataan-kenyataan yang peneliti temui pada sikap siswa di dalam proses pembelajaran tersebut di atas, peneliti berpendapat bahwa aktivitas siswa di SMP Negeri 5 dalam pembelajaran PKn sangat kurang. Dalam hal ini peneliti berani mengungkapkan karena memang aktivitas siswa SMP Negeri 5 Kota Tebing Tinggi masih jauh dari pengertian aktivitas yang diungkapkan dari para ahli, seperti Paul D. Dierich dalam Oemar Hamalik (2001: 173), mengemukakan bahwa jenis aktivitas dalam kegiatan lisan atau oral adalah mengemukakan suatu fakta atau prinsip, menghubungkan suatu kejadian, mengajukan pertanyaan, memberi saran, mengemukakan pendapat, wawancara, diskusi dan interupsi. Berdasarkan pengamatan atau observasi pendahuluan yang peneliti lakukan, ditemukan bahwa siswa SMP Negeri 5 Kota Tebing Tinggi dalam melaksanakan diskusi kelas jarang sekali mengemukakan pendapat, mengajukan pertanyaan, apalagi mengajukan saran. Karena aktivitas siswa yang rendah itu, hasil belajar yang diperoleh juga menjadi rendah. Hal ini dapat kita lihat dari nilai rata-rata hasil ujian semester II Kelas VII tahun pelajaran 2016/2017 sangat rendah di bawah KKM yang diharapkan yaitu 65 .

Berdasarkan pengalaman yang peneliti hadapi di dalam proses 
pembelajaran PKn yang tidak aktif maka peneliti berusaha mencarikan model pembelajaran lain, sehingga pembelajaran lebih bermakna dan lebih berkualitas. Model pembelajaran yang akan peneliti coba untuk melakukannya adalah model pembelajaran Kooperatif tipe Jigsaw. Ketertarikan peneliti mengambil model pembelajaran kooperatif tipe Jigsaw, karena peneliti melihat dalam model pembelajaran kooperatif tipe Jigsaw semua anggota kelompok diberi tugas dan tanggungjawab, baik individu maupun kelompok. Jadi, keunggulan pada pembelajaran kooperatif Jigsaw dibanding dengan diskusi yaitu seluruh anggota dalam kelompok harus bekerja sesuai dengan tugas yang diberikan, sebab tugas itu ada yang merupakan tanggung jawab individu dan ada pula tanggung jawab kelompok.

Dalam penelitian ini peneliti merujuk pada penelitian yang sudah dilakukan oleh beberapa tenaga pendidikan yang menggunakan model Jigsaw dalam perbaikan pembelajaran salah satunya adalah Martiningsih (2006) di SMA Negeri 1 Padang Panjang Kelas XI, dalam penelitian tindakan kelas tersebut disimpulkan bahwa Penggunaan model Jigsaw akan meningkatkan minat dan motivasi belajar sehingga akan meningkatkan hasil belajar.

Model pembelajaran kooperatif jigsaw merupakan model pembelajaran kooperatif dimana siswa belajar dalam kelompok kecil yang terdiri dari $4-6$ orang (sesuai dengan jumlah siswa) secara heterogen dan bekerja sama saling ketergantungan yang positif dan bertanggung jawab atas ketuntasan bagian materi pelajaran yang harus dipelajari dan menyampaikan materi tersebut kepada anggota kelompok yang lain. Model Pembelajaran kooperatif jigsaw didesain untuk meningkatkan rasa tanggung jawab siswa terhadap pembelajarannya sendiri dan juga pembelajaran orang lain. Siswa tidak hanya mempelajari materi yang diberikan, tetapi mereka juga harus siap memberikan dan mengajarkan materi tersebut pada anggota kelompoknya yang lain. Dengan demikian, "siswa saling tergantung satu dengan yang lain dan harus bekerja sama secara kooperatif untuk mempelajari materi yang ditugaskan. Pada model pembelajaran kooperatif tipe Jigsaw, terdapat kelompok asal dan kelompok ahli. Kelompok asal yaitu kelompok induk siswa yang beranggotakan siswa dengan kemampuan, asal, dan latar belakang keluarga yang beragam. Kelompok asal merupakan gabungan dari beberapa ahli. Kelompok ahli yaitu kelompok siswa yang terdiri dari anggota kelompok asal yang berbeda yang ditugaskan untuk mempelajari dan mendalami topik tertentu dan menyelesaikan tugas-tugas yang berhubungan dengan topiknya untuk kemudian dijelaskan kepada anggota kelompok asal. Dalam pembelajaran kooperatif tipe Jigsaw kegiatan dilakukan dalam tiga tahapan yaitu : tahap I (kooperatif asal), tahap II 
(kelompok ahli), tahap III (kelompok gabungan). Untuk meningkatkan aktivitas siswa perlu ada motivasi, baik motivasi intrinsik maupun motivasi ekstrinsik. Dalam hal ini peneliti hanya meneliti sampai aktivitas siswa, tidak meneliti sampai hasil belajar siswa.

Dengan menerapkan model pembelajaran kooperatif tipe Jigsaw dalam materi pelajaran Pendidikan Kewarganegaraan di SMP Negeri 5 Kota Tebing Tinggi tahun pelajaran 2016/2017 aktivitas siswa dapat meningkat.

Berdasarkan latar belakang masalah di atas, maka dapat diidentifikasi masalah sebagai berikut:

a. Siswa kurang memperhatikan dalam pembelajaran.

b. Siswa kurang berani dalam mengemukakan pendapat.

c. Adanya siswa beranggapan bahwa dalam belajar kelompok tidak perlu semua bekerja.

d. Adanya siswa yang suka membicarakan hal lain, yang tidak berhubungan dengan tugas kelompok.

e. Tanggung jawab siswa terhadap tugas masih rendah.

f. Adanya anggota kelompok yang tidak mau menerima pendapat teman.

Sesuai dengan kemampuan waktu dan tenaga yang peneliti miliki, maka peneliti memberi batasan masalah:

a. Siswa kurang berani dalam mengemukakan pendapat. b. Tanggung jawab siswa terhadap tugas masih rendah.

c. Motivasi siswa dalam mengikuti pembelajaran kurang.

Berdasarkan batasan masalah yang telah ditetapkan dalam pembelajaran PKn dengan menggunakan pembelajaran kooperatif tipe Jigsaw, maka dapat dirumuskan masalah sebagai berikut:

a. Sejauh mana manfaat penerapan model pembelajaran kooperatif tipe Jigsaw terhadap pembelajaran PKn?

b. Sejauh mana aktivitas belajar siswa dalam pelaksanaan pembelajaran kooperatif tipe Jigsaw?

c. Sejauh mana pengaruh motivasi terhadap siswa dalam mengikuti pelajaran?

Tujuan yang hendak dicapai dalam penelitian ini adalah untuk peningkatan aktivitas belajar siswa dan motivasi belajar Pendidikan Kewarganegaraan melalui model pembelajaran kooperatif tipe Jigsaw".

\section{METODE PENELITIAN}

$\begin{array}{llr}\text { Tempat } & \text { penelitian } & \text { adalah } \\ \text { tempat yang } & \text { digunakan } & \text { dalam } \\ \text { melakukan } & \text { penelitian } & \text { untuk }\end{array}$
memperoleh data yang diinginkan. Penelitian ini bertempat di SMP Negeri 5, Jalan Letda Sujono Kec. Bajenis Kota, Kota Tebing Tinggi Tahun Pelajaran 2016/2017.

Waktu penelitian adalah waktu berlangsungnya penelitian 
atau saat penelitian ini dilangsungkan. Penelitian ini dilaksanakan pada bulan April-Juni 2017 (semester II tahun pelajaran 2016/2017).

Subjek penelitian adalah siswa Kelas VII yang berjumlah 24 orang, terdiri dari 13 orang laki-laki dan 11 orang perempuan di SMP Negeri 5 Kota Tebing Tinggi tahun pelajaran 2016/2017.

Penelitian yang dilakukan oleh peneliti berupa Penelitian Tindakan Kelas (PTK), yaitu suatu kegiatan penelitian yang dilakukan di kelas dalam arti luas. Suharsimi Arikunto (2006 : 2) memandang Penelitian Tindakan Kelas sebagai bentuk penelitian yang bertujuan untuk meningkatkan hasil belajar siswa, sehingga penelitian harus menyangkut upaya guru dalam bentuk proses pembelajaran. PTK, selain bertujuan untuk meningkatkan hasil belajar, juga untuk meningkatkan kinerja guru dan dosen dalam proses pembelajaran. Dengan kata lain, PTK bukan hanya bertujuan untuk mengungkapkan penyebab dari berbagai permasalahan yang dihadapi, tetapi yang lebih penting adalah memberikan pemecahan berupa tindakan untuk mengatasi masalah.

Alat pengumpul data dalam penelitian ini adalah tes yang disusun oleh Guru yang fungsinya adalah: (1) Untuk menentukan seberapa baik siswa telah menguasai bahan pelajaran yang telah diberikan dalam waktu tertentu; (2) Untuk menentukan apakah suatu tujuan telah tercapai; dan (3) Untuk memperoleh suatu nilai (Arikunto, Suharsimi, 2006: 19). Sedangkan tujuan dari tes adalah untuk mengetahui ketuntasan belajar siswa secara individual maupun secara klasikal. Disamping itu untuk mengetahui letak kesalahankesalahan yang dilakukan siswa sehingga dapat dilihat dimana kelemahannya, khususnya pada pokok bahasan materi ajar yang belum tercapai. Untuk memperkuat data yang dikumpulkan, maka juga digunakan metode observasi (pengamatan) yang dilakukan oleh teman sejawat untuk mengetahui dan merekam aktifitas Guru dan siswa dalam proses belajar mengajar.

Untuk mengetahui kefektifan suatu metode dalam kegiatan pembelajaran perlu diadakan analisis data. Pada penelitian ini menggunakan teknik analisis dekriptif kualitatif, yaitu suatu metode penelitian yang bersifat menggambarkan kenyataan atau fakta sesuai dengan data yang diperoleh dengan tujuan untuk mengetahui pemahaman yang dicapai siswa, juga untuk memperoleh respon siswa terhadap kegiatan pembelajaran serta aktivitas siswa selama proses pembelajaran. Untuk menganalisi tingkat keberhasilan atau presentase keberhasilan siswa setelah proses belajar mengajar setiap putarannya dilakukan dengan cara memberikan evaluasi berupa soal tes tertulis pada setiap akhir putaran/ siklus. Data yang diperoleh dianalisa secara 
kolaboratif dengan teman sejawat dan hasilnya dijadikan sebagai bahan penyusunan rencana tindakan berikutnya. Analisa data dilakukan setiap selesai 1 kali pertemuan tatap muka dan setiap akhir siklus. Data dianalisa secara kualitatif yaitu lembaran observasi dan catatan lapangan. Analisa kualitatif untuk catatan lapangan dan lembaran observasi dilakukan dengan jalan membandingkan keaktifan siswa pada siklus satu dengan keaktifan siswa siklus dua.

Penelitian ini dapat dikatakan berhasil dan tidak perlu dilanjutkan ke siklus berikutnya apabila hasil dari pengelolaan pembelajaran, yaitu persentase pengelolaan pembelajaran aktivitas siswa dan motivasi siswa diatas $85 \%$.

\section{HASIL PENELITIAN DAN PEMBAHASAN}

Untuk diketahui pada pertemuan I ini peneliti belum lagi menerapkan model pembelajaran Jigsaw, tetapi hanya berbentuk ceramah bervariasi disertai dengan penugasan. Di akhir pembelajaran baru peneliti membentuk kelompok untuk persiapan pembelajaran jigsaw pada pertemuan berikutnya. Pada pertemuan 2 peneliti telah menggunakan model pembelajaran kooperatif Jigsaw, ternyata seperti yang kita lihat dalam tabel, terjadi peningkatan aktivitas siswa. Peningkatan terjadi pada semua aspek, namun yang paling rendah aktivitasnya adalah dalam hal memberi saran. Ini disebabkan karena tingkat pengetahuan siswa yang masih rendah. Kemudian peningkatan aktivitas yang agak tinggi adalah dalam menjawab pertanyaan siswa maupun guru. Ini disebabkan karena siswa diberi dorongan atau motivasi, sehingga secara bertahap timbul keberanian siswa untuk menjawab pertanyaan. Berdasarkan kumpulan data yang diperoleh dari kolaborasi dengan teman sejawat serta catatan lapangan yang ada pada peneliti, ternyata sebagian besar siswa belum mampu menyelesaikan tugas dengan optimal, baik pada tahap kooperatif asal (tahap I), tahap ahli (tahap II), maupun tahap ke III. Tingkat keaktifan siswa sangat rendah dalam pembelajaran. Hal ini menunjukkan bahwa tujuan yang hendak dicapai sehubungan dengan pelaksanaan tindakan ini belum tercapai secara optimal. Menurut pengamatan peneliti kegagalan siswa tampak dengan jelas dalam memanfaatkan waktu. Siswa belum mampu memanfaatkan waktu sesuai dengan yang dialokasikan untuk setiap tahapan. Agar siswa dapat menyelesaikan tugas-tugas yang diberikan tersebut, maka perlu diberikan perpanjangan waktu. Akibat dari perpanjangan waktu ini adalah sedikitnya waktu yang tersedia untuk kegiatan presentasi hasil kerja kelompok. Bila dicermati, penyebab dari kegagalan siswa dalam mengerjakan tugas saat proses pembelajaran bersumber dari hal-hal berikut: 
a. Siswa belum memahami tentang langkah-langkah kerja atau tahapan -tahapan pembelajaran yang harus dilalui. Misalnya apa yang seharusnya dilakukan dalam tahapan I (kooperatif asal), tahapan II (kooperatif ahli), dan seterusnya.

b. Pada tahap III, ada siswa yang tidak mampu menyampaikan ilmu yang diperdapatnya dari kelompok ahli secara sistematis, sehingga teman sekelompoknya tidak dapat menyerap pelajaran sebagaimana mestinya.

c. Masih ada siswa yang suka mengganggu teman, sehingga terkendala dalam menyelesaikan tugas.

Berdasarkan permasalahan dan kegagalan di atas, maka peneliti mencarikan solusinya yaitu dengan memberikan arahan kembali kepada siswa tentang langkah-langkah kerja kelompok pada model pembelajaran kooperatif Jigsaw, sehingga kegiatan pada siklus berikutnya dapat berjalan dengan lancar seperti yang diharapkan.

Dari penelitian di atas terlihat sudah terjadinya perubahan yang cukup berarti untuk semua aktivitas yang diteliti. Khusus aktivitas yang ke enam, yaitu mempresentasikan hasil kerja kelompok memang tidak ada perubahan, karena presentase berdasarkan kelompok yang terdiri dari empat kelompok, sehingga yang tampil satu orang per kelompok. Sebagaimana yang dilakukan pada siklus I, pada siklus II juga dilakukan diskusi yang mendalam terhadap deskripsi data yang dipaparkan di atas. Di mana pada lembaran observasi aktivitas belajar siswa terjadi perubahan keaktifan yang cukup berarti. Pada awalnya (siklus I) siswa belum berani dan ragu-ragu untuk menyampaikan pendapat, namun pada siklus II sudah ada keberanian. Demikian juga dalam mengerjakan tugas kelompok atau diskusi, secara keseluruhan siswa sudah menunjukkan aktivitas yang baik.

\section{Pembahasan}

Berdasarkan hasil yang diperoleh dari pengumpulan data yang menunjukkan hasil yang baik adalah mengenai model pembelajaran yang diterapkan. Menurut pengakuan siswa, model pembelajaran kooperatif Jigsaw disenangi oleh siswa. Sehingga membawa dampak positif terhadap yang lain, seperti dapat melatih siswa untuk bertanggungjawab. Kemudian dampak lain yang sangat berpengaruh dengan disenanginya model pembelajaran yang diberikan adalah siswa menjadi termotivasi untuk bertanya, terutama saat berdiskusi. Dengan termotivasinya siswa saat berdiskusi, akhirnya aktivitas belajar siswa menjadi meningkat, sehingga dapat mendorong siswa untuk belajar lebih baik. Berikut ini dipaparkan seluruh hasil yang diperoleh dari data yang dikumpulkan baik data siklus I maupun data siklus II. Tujuannya agar dapat dilihat kemajuan apa yang 
Netti Simanungkalit : Upaya Peningkatan Aktivitas ...

dialami selama penelitian dilaksanakan.

\begin{tabular}{|c|c|c|c|}
\hline \multirow[t]{2}{*}{ No } & \multirow{2}{*}{$\begin{array}{c}\text { Aktivitas yang } \\
\text { diamati }\end{array}$} & \multicolumn{2}{|c|}{ Keterangan } \\
\hline & & Siklus I & Siklus II \\
\hline 1 & $\begin{array}{l}\text { Mendengarkan } \\
\text { penjelasan guru } \\
\text { dengan tekun }\end{array}$ & $9(37,5 \%)$ & $20(83,5 \%)$ \\
\hline 2 & $\begin{array}{lr}\text { Ada usaha } & \text { dan } \\
\text { motivasi } & \text { untuk } \\
\text { mempelajari } & \text { bahan } \\
\text { pelajaran } & \text { atau } \\
\text { stimulus } & \text { yang } \\
\text { diberikan guru } & \end{array}$ & $6(25 \%)$ & $17(71 \%)$ \\
\hline 3 & $\begin{array}{l}\text { Dapat bekerjasama } \\
\text { dan berhubungan } \\
\text { dengan siswa lain }\end{array}$ & $5(20,3 \%)$ & $19(79,3 \%)$ \\
\hline 4 & $\begin{array}{l}\text { Mengemukakan } \\
\text { pendapat, bertanya, } \\
\text { berkomentar pada } \\
\text { siswa atau guru }\end{array}$ & $7(29,2 \%)$ & $18(75 \%)$ \\
\hline 5 & $\begin{array}{l}\text { Menyelesaikan tugas } \\
\text { kelompok }\end{array}$ & $14(58,3 \%)$ & $20(83,5 \%)$ \\
\hline 6 & $\begin{array}{l}\text { Mempresentasikan } \\
\text { hasil kerja kelompok }\end{array}$ & $3(83,3 \%)$ & $4(100 \%)$ \\
\hline
\end{tabular}

\section{SIMPULAN}

Dari hasil pengamatan peneliti tentang aktivitas belajar siswa di Kelas VII SMP Negeri 5 Kota Tebing Tinggi, ternyata model pembelajaran kooperatif tipe Jigsaw dapat meningkatkan aktivitas belajar siswa. Ini dapat peneliti lihat dari beberapa hal sebagai berikut:

a. Siswa dapat mengikuti proses pembelajaran lebih bergairah dan bersemangat,

b. Timbulnya keberanian siswa dalam menyampaikan ide atau pikiran,

c. Tumbuhnya rasa percaya diri siswa dalam mengemukakan pendapatnya, d. Meningkatnya rasa tanggungjawab siswa dalam mengikuti pembelajaran,

e. Sangat kurang sekali siswa yang berkeliaran dan maupun mengganggu teman.

Dengan demikian berarti model pembelajaran kooparatif Jigsaw sangat cocok diterapkan dalam proses pembelajaran PKn di SMP Negeri 5 Kota Tebing Tinggi.

\section{DAFTAR RUJUKAN}

Arikunto, Suharsimi. 2006. Penelitian Tindakan Kelas. Jakarta: Bumi Aksara

Depdiknas. 2005. Pendidikan Kewarganegaraan, Kurikulum dan Silabus Pendidikan Kewarganegaraan. Jakarta: Depdiknas

Depdiknas. 2005. Pendidikan Kewarganegaraan, Strategi dan Metode Pembelajaran Pendidikan Kewarganegaraan. Jakarta: Depdiknas.

Sanjaya, Wina. 2006. Strategi Pembelajaran Berorientasi Proses Standar Proses Pendidikan. Jakarta: Kencana Prima.

Undang-Undang Republik Indonesia No. 20 tahun 2003 tentang sistem pendidikan nasional. Jakarta: Depdiknas.

Yasmin, Martinis. 2006. Strategi Pembelajaran Berbasis Kompetensi. Jakarta: Gaung Persada Press Jakarta. 